\title{
原体照射法による定位的放射線照射の線量分布の検討
}

\author{
藪谷俊峰・鈴木昇一1) · 加藤正直 $\cdot$ 安野泰史 ${ }^{1)}$ \\ 藤田保健衛生大学病院放射線部 \\ 1 ) 藤田保健衛生大学衛生学部放射線技術学科
}

を定位放射線照射(stereotactic irradiation: STI)，その うち 1 回照射をSRS, 分割照射を定位放射線治療

スウェーデンの脳外科医 Lars Leksellはメスの代わ (stereotactic radiotherapy: SRT) と定義し, 用語の統一 を図るよう提唱している。

このSTIを行う方法は，コバルト60- $\gamma$ 線を用いた 射し，病巣部を破壊する方法を定位手術的照射(stereotactic radiosurgery: SRS) と定義した ${ }^{1)}$. 一方，厚生省 がん研究阿部班では，定位手術枠などを用い，治療中 を通じて照射中心精度が $1 \mathrm{~mm}$ 以内である放射線治療 gamma unit ${ }^{2-5)}$, Bragg peakを用いた陽子もしくは重 粒子線治療法6,7), 医療用直線加速装置 (linear accelerator)を用いたmultiple non-coplanar converging arcs

\section{Study of Dose Distribution for Stereotactic Irradiation by Conformational Radiotherapy}

\section{TOSHIMINE YABUTANI, SHOUICHI SUZUKI, "1) MASANAO KATO, and HIROFUMI ANNO ${ }^{1)}$}

Department of Radiology, Fujita Health University Hospital

1) Department of Radiological Technology. Fujita Health University School of Health Sciences

Received Apri1 28, 2000; Revision accepted Oct. 3, 2000; Code No. 852

\section{Summary}

Current stereotactic irradiation techniques with high-energy photon beams are based either on gamma units that use 201 stationary cobalt beams or on isocentric linear accelerators. The techniques using linear accelerators are divided into multiple non-coplanar techniques and others, all of which have their respective physical characteristics, such as precision of dose convergence and isodose distribution. Conformational stereotactic irradiation was developed in order to improve the precision of dose convergence, and we compared isodose distributions to conventional multiple shots of stereotactic irradiation by the film method using a globular Mix-Dp phantom with a diameter of $20 \mathrm{~cm}$. Results were as follows:(1) isodose distribution was shown as curved lines with conformational stereotactic irradiation, rather than the simple ovals with multiple-isocenter stereotactic irradiation; (2) the precision of dose convergence of simple shaped conformational stereotactic irradiation was equal to that of multiple-isocenter stereotactic irradiation; (3) the possibility existed of deterioration of the precision of dose convergence according to complex shaped conformational stereotactic irradiation.

Key words: Stereotactic irradiation, Conformational radiotherapy, Dose distribution, Measurement of dose convergence, Linear accelerator 


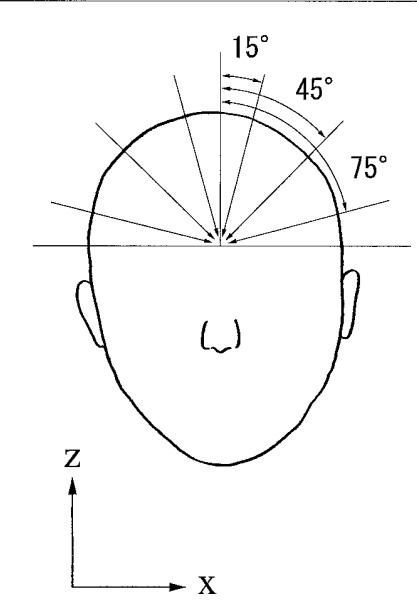

Fig. 1 Angles of arcs of the multiple non-coplanar converg ing arcs technique with isocentric linear accelerators used up to 6 arcs, each from $20^{\circ}$ to $130^{\circ}$ (b) with treatment couch angles of $75^{\circ}, 45^{\circ}, 15^{\circ},-15^{\circ},-45^{\circ}$, and $-75^{\circ}(\mathrm{a})$

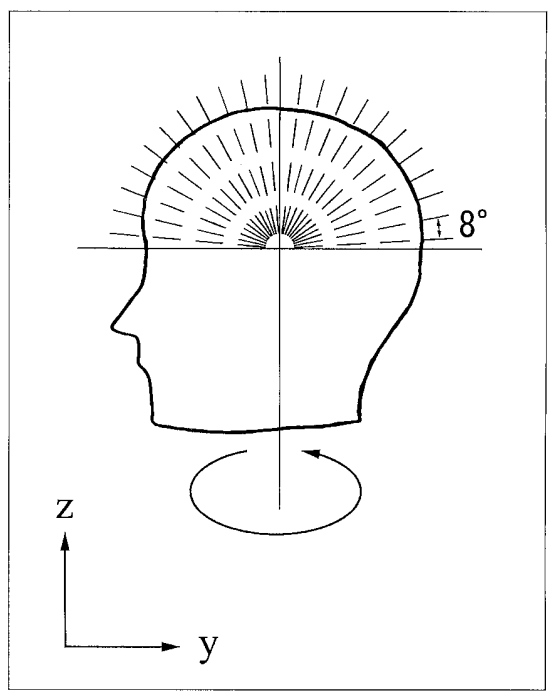

Fig. 2 Dose delivery to the target of precessional convergent irradiation with isocentric linear accelerators.

The irradiated angle of the gantry was $8^{\circ}$ along with 11 shots.
法8 13) (以下, MCA法), 同じく直線加速装置を用いた 歳差集光照射法 (precessional convergent irradiation) ${ }^{14 \sim 19)}$, 直線加速装置を用いたその他の方法20〜22) 等がある。

いずれの照射法も微小な標的に集中して大線量を与 え，なおかつ健常組織には影響を少なくするため，各 種の技術と工夫が盛り込まれている，そして，その治 療計画の方法も同様に特徴がある. gamma unitの治療 計画は球状の照射野の位置と数, および線量配分，コ リメータの大きさなどを変化させながら，試行錯誤的 に最適な線量分布を作成する23)。コリメータヘルメッ トのコリメータの一部をpluggingして塞ぐことで線量 分布をある程度变形できるが，大きな標的や複雑な形 状の標的には，複数の照射野を三次元的に組み合わせ ることで標的に近い形の線量分布を作成する ${ }^{23)}$. そし て，通常50\%当線量曲線で病変を取り囲むため，照射 計画では標的に一致しているが標的内部には多数の小 ットスポットが存在する24)。このようなtumor dose inhomogeneityは，合併症の出現と有意に相関するとの 報告もある25).

一方，直線加速装置を用いたSTIにおける照射計画

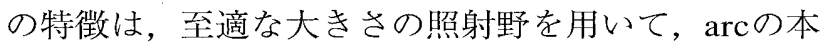
数や角度, beam weight等を变化させることにより， 可能ならば 1 個のアイソセンタへの照射ですまないか と工夫する ${ }^{24)}$. しかし，それが不可能ならばgamma unit的なmultiple isocentersを用いたSTI (以下，M-STI) にならざるを得ない24).

今般，われわれは線量分布の改善を求め, 直線加速 装置を用いたSTI と原体照射法26 29)を組み合わせた原 体定位放射線照射 (以下, 原体STI) を考案 ${ }^{30)}$ ᄂ, 線量
分布の集中度 (以下，集光度)の検討を行った。この原 体STIは照射角度ごとにコリメータを操作して標的形 状に一致した照射野を得るよう，標的に一致した高線 量域を得る手法である.STIの方法はMCA法と歳差集 光照射法を採用した.

\section{1. 方 法}

原体STIとM-STIの等線量曲線図を取得し，集光度 を検討した，測定用フィルムを挟み达み直径 $20 \mathrm{~cm} の$ 球になるように作製した半球状のMix- $\mathrm{Dp}^{31}$ )ファント ム 2 個を使用し，フィルム法32,33)により等線量曲線図 を得た。一連の測定はまとめて標潐照射フィルムと同 時処理し，吸収線量に変換して評価した。MCA法は 宮原ら ${ }^{13)}$ の方法を採用し，ファントム中心に向け，正 中線より左右に $15^{\circ}, 45^{\circ}, 75^{\circ}$ の $\operatorname{arc}$ 数 6 , $\operatorname{arc}$ 角度 $110^{\circ}$ に て照射した(Fig. 1). 歳差集光照射法は $8^{\circ}$ 刻みの11門

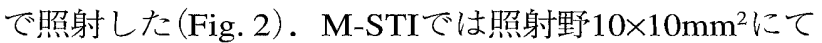
shotを重ねた。使用したフィルムおよび現像処理条件 によりフィルム黒化度の最高值が約 2.0 になるう, 最大標的線量は1Gyに設定した。

臨床において原体照射法を用いる場合は，複雑な形 状の標的に対してなるべく一致した照射野を設定す る。そのため, 一定の標的形状は存在しない. そこで 本研究では最も簡単な標的形状である $10 \mathrm{~mm} \phi$ の照射 野 2 個並べたものに相当する棈球体を基準標的形状と して比較検討を行った。

なお，本装置におけるM-STIはshot間のギャップが 
Ommの時，ホットスポットの発生が抑制されたため， M-STIのギャップは $0 \mathrm{~mm}$ とした.

MCA法における原体STIでは体軸から横方向にのば した線量分布が良好な結果を得たので，その方向にて 検討を行った。 MCA法は10mm $\phi$ の照射野 2 個並べた M-STI, $10 \mathrm{~mm} \phi$ の照射野 2 個のM-STIに相当する原体 STI, さらに少し形状を複雑にする目的で $10 \mathrm{~mm} \phi$ の照 射野 3 個のM-STIに相当する原体STIにて比較検討し た。

一方，歳差集光照射法における原体STIでは体軸方 向にのばした原体STIの線量分布が良好な結果を得た ので, その方にて検討を行った. 歳差集光照射法は $10 \mathrm{~mm} \phi$ の照射野 2 個並べたM-STI，10mm $\phi$ の照射野 2 個のM-STIに相当する原体STI, さらに $10 \mathrm{~mm} \phi$ 照 射野 3 個のM-STIに相当する原体STI, さらに歳差集 光照射法では光照射野を体軸方向に長い矩形に固定す る (以下, 矩形固定) と棈円球の治療容積輪郭が得られ るため $10 \mathrm{~mm} \phi$ の照射野 2 個のM-STIに相当する照射野 $10 \times 20 \mathrm{~mm}^{2}$ の矩形固定照射野を用いた歳差集光照射法 にて比較検討した。

原体STIの照射角度ごとのコリメータ開度(アイソセ ンタ上での一辺の長さで表す)をFig. 3に示す. $10 \mathrm{~mm} \phi$ の照射野 2 個のM-STIに相当する原体STIの照射角度 ごとのコリメータ開度Lの近似式は $\mathrm{L}=2 \mathrm{r}(1+\sin \theta)$ であ り $10 \mathrm{~mm} \phi$ の照射野3個のM-STIに相当する原体STI のコリメータ開度 $\mathrm{L}^{\prime} の$ 近似式は $\mathrm{L}^{\prime}=2 \mathrm{r}(1+2 \sin \theta)$ であ る。この式は平行ビームの場合に成り立つ式である が，同一平面上に同じ直径を持つ二つの円が接してい るとき，二つの円外にある 1 点から接線を引いた 2 本 の接線が弓ける. 円外の 1 点から二つの円の接点へ引 いた直線と 2 本の接線の開き角は異なる。すなわち, このことを原体照射に当てはめた場合, 左右のコリメ 一夕開度は異なる。しかし, 線源回転中心間距離 $80 \mathrm{~cm}$ において最大 $3 \mathrm{~cm}$ の小さな照射野ではコリメー タ開度の左右の差は無視できると考える。

\section{1-1 線量分布形状}

取得した各照射法の等線量分布図から，線量分布の 形状を比較した。

\section{1-2 照射面積比}

今回は冠状断面の照射面積比をSTIの集光度の指標 として検討を行った．各照射法の等線量分布から90\% 以上の面積と $50 \%$ 以上の面積との比より高線量域の集 光度, $50 \%$ 以上の面積と $10 \%$ 以上の面積との比より低 線量域の集光度を求めた. 今回の万法では理論的に歳 差集光照射法は冠状断面と矢状断面とは等線量分布図 が同一形状になり，軸位断面は円形になる。一方，

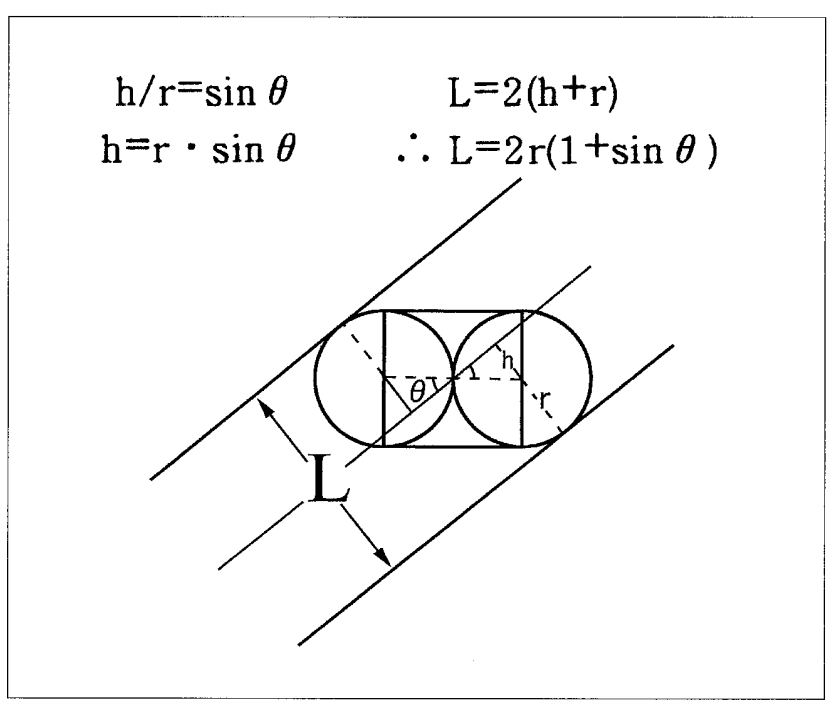

Fig. 3 The conformational stereotactic irradiation field $L$ that was calculated with a model of $10 \mathrm{~mm} \phi$ in diameter and two-shot multiple isocenter stereotactic irradiation.

MCA法は冠状断面と軸位断面とは等線量分布図が同 一形状になり，矢状断面は円形になる。そのため，冠 状断面の照射面積比のみでSTIの集光度の指標になる と考えた.

集光度の測定のために，4MeV直線加速装置 NELAC-1004B (日本電気株式会社製) から発生する 4MV X線(TMR20/TMR10による線質評価は3.6MV)を 用いた. 歳差集光照射法は回転イスの代わりにレコー ドプレーヤのターンテーブルを加工して使用し，MixDp ファントムを毎分約15回転で回転させた.フィル ムはGRAVURE FILM GN-135T（富士写真フイルム株 式会社製)，等濃度記録装置はPDI-10(コニカ株式会社 製)，面積計は複式プラニメータKP-13/15 (株式会社島 津製作所製)，自動現像機はFIP-4000(富士写真フイル 么株式会社製) を使用し, 現像処理条件は現像液温度 $23.0^{\circ} \mathrm{C}$ ，処理時間 5 分 30 秒を用いた。

\section{2. 結 果}

\section{2-1 線量分布曲線の形状}

MCA法10mm $\phi 2$ 個のM-STIの線量分布をFig. 4 に 示す. 高線量域は楕円形であるが50\%以下の低線量域 では球形の照射野を二つ並べた影響が現れ中央部がく びれた形状を示した。

MCA法の原体定位放射線照射 (以下，原体MCA法) の $10 \mathrm{~mm} \phi 2$ 個に相当する照射野の線量分布をFig. 5 に 示す。 $90 \%$ 線量曲線はほぼ円形を示したが，70\%以下 の線量曲線は卵形を示した。さらに，10mm $\phi 3$ 個に 相当する原体MCA法の線量分布をFig. 6に示す. $10 \mathrm{~mm} \phi 2$ 個の原体MCA法と形状的に似た線量分布曲

2001 年 2 月 


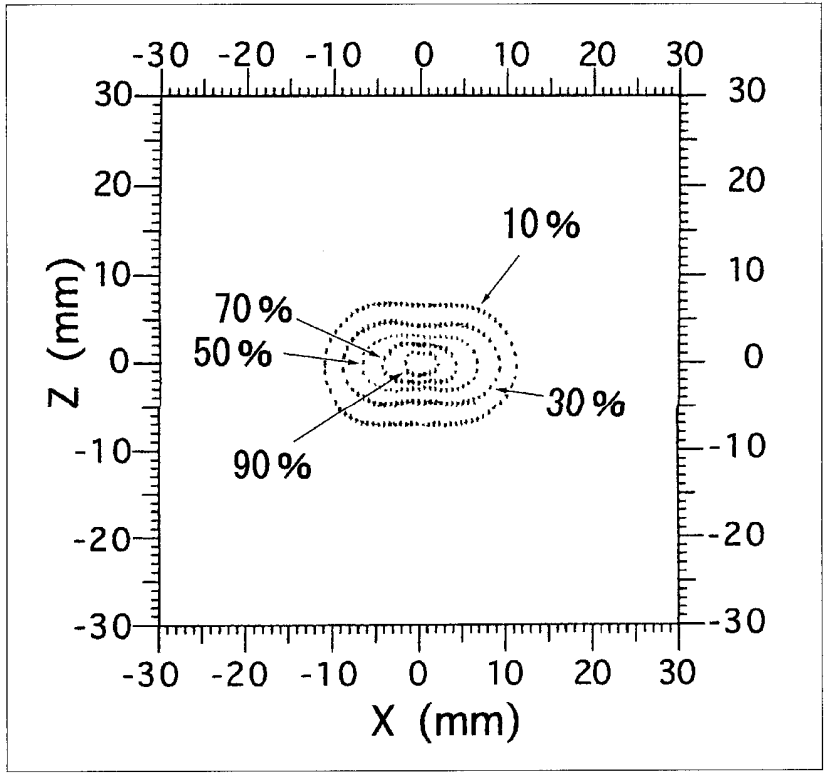

Fig. 4 Coronal isodose distribution of two-shot multiple isocenter fields of $10 \times 10 \mathrm{~mm}^{2}$ by multiple non-coplanar converging arcs for the globular Mix-Dp phantom of $20 \mathrm{~cm}$ in diameter with $4 \mathrm{MV}$ x-rays.

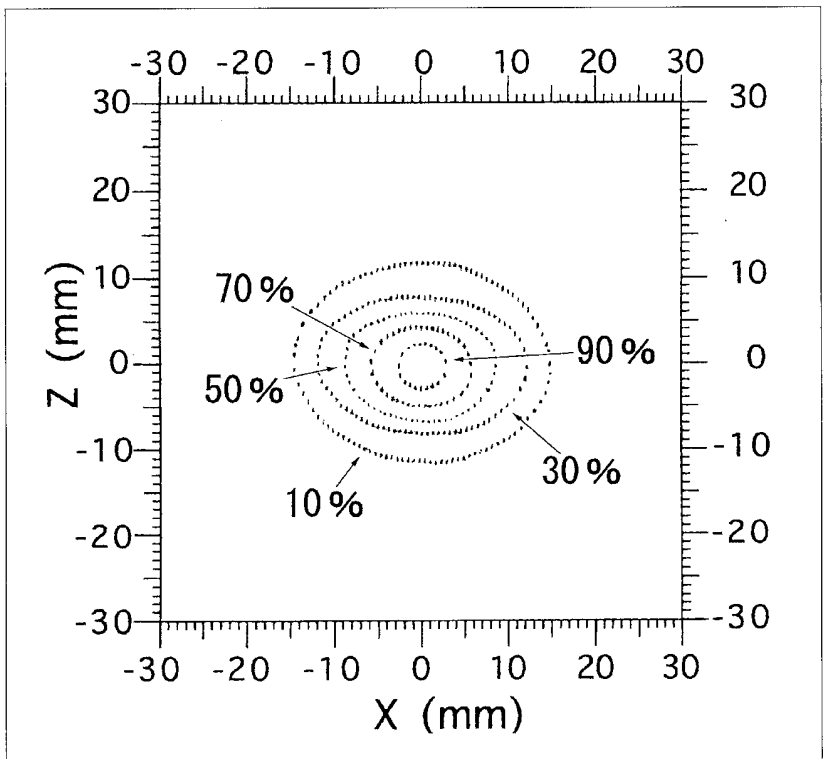

Fig. 6 Coronal isodose distribution of conformational multiple non-coplanar converging arcs matched for three fields of $10 \mathrm{~mm}$ in diameter for the globular Mix-Dp phantom of $20 \mathrm{~cm}$ in diameter with $4 \mathrm{MV} \mathrm{x}-$ rays.

線が得られた。

一方，歳差集光照射法では $10 \mathrm{~mm} \phi 2$ 個のM-STIの 線量分布をFig. 7に示す. $90 \%$ から50\%線量曲線は線 量分布の中心が頭頂部側に偏った瓢箪形を示した。

歳差集光照射法における $10 \mathrm{~mm} \phi$ の照射野 2 個のMSTIに相当する矩形固定の照射野の線量分布をFig. 8 に

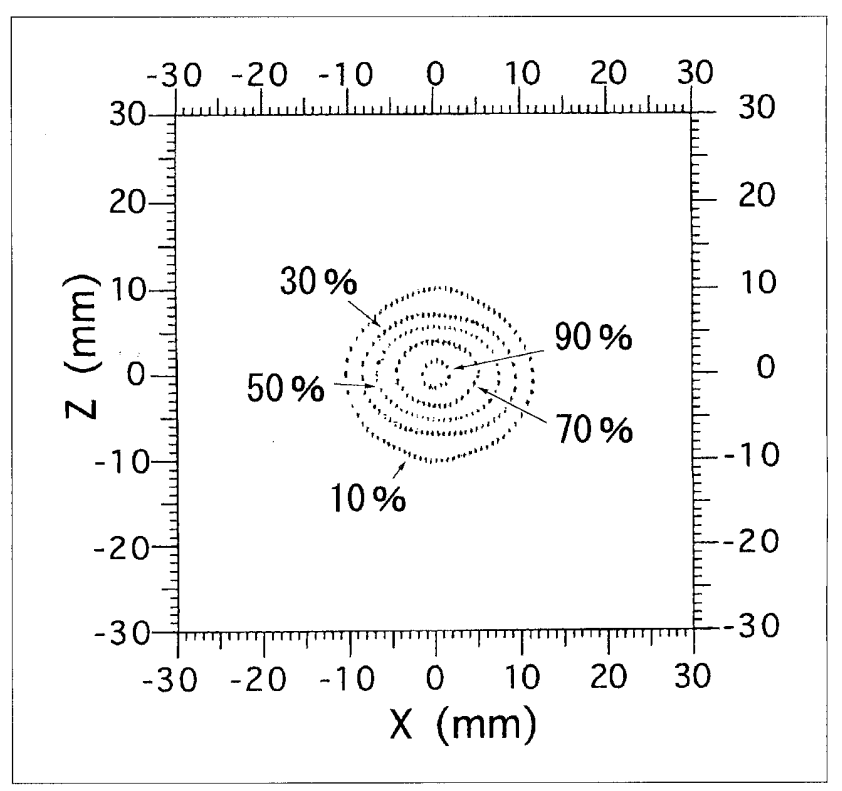

Fig. 5 Coronal isodose distribution of conformational multiple non-coplanar converging arcs matched for two fields of $10 \mathrm{~mm} \phi$ in diameter for the globular Mix-Dp phantom of $20 \mathrm{~cm}$ in diameter with $4 \mathrm{MV} \mathrm{x}$ rays.

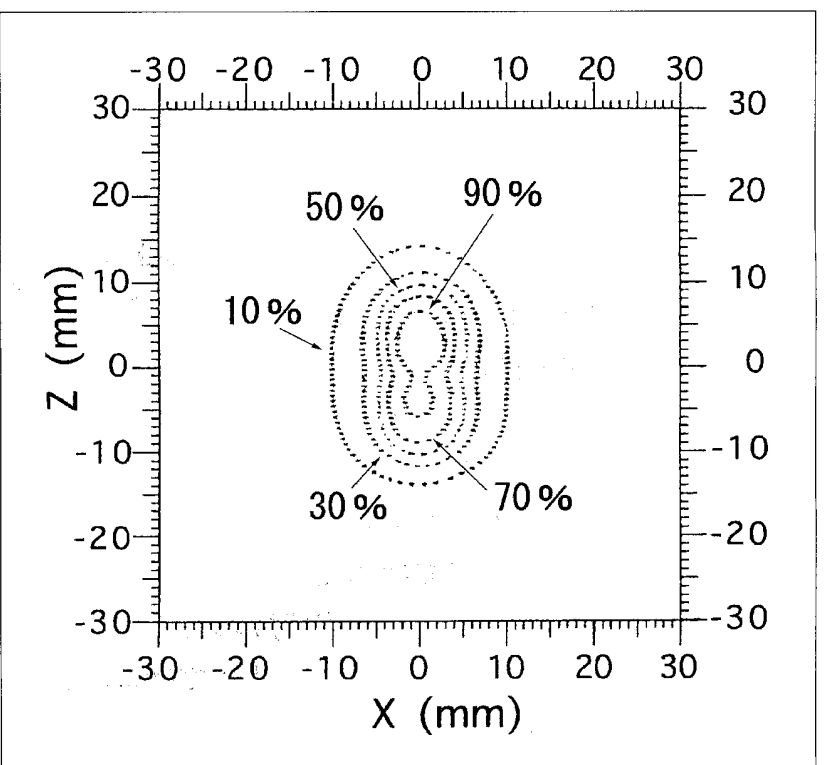

Fig. 7 Coronal isodose distribution of two-shot multiple isocenter fields $10 \times 10 \mathrm{~mm}^{2}$ by precessional convergent irradiation for the globular Mix-Dp phantom of $20 \mathrm{~cm}$ in diameter with $4 \mathrm{MV} \mathrm{x}$-rays.

示す． 90\%から30\%線量曲線は楕円形状を示したが, 10\%線量曲線はラグビーボール様の形状を示した。

一方, $10 \mathrm{~mm} \phi 2$ 個のM-STIに相当する歳差集光照 射法の原体STIの線量分布をFig. 9に示す。線量分布曲 線はすべての曲線で楕円形であった。

$10 \mathrm{~mm} \phi 3$ 個に相当する歳差集光照射法の原体STIの 


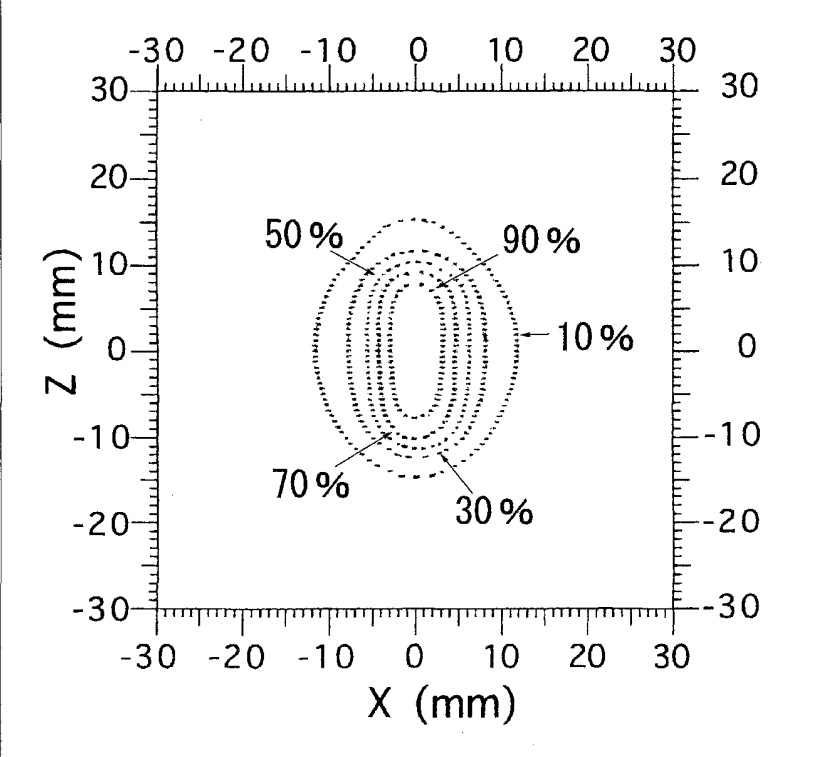

Fig. 8 Coronal isodose distribution of precessional convergent irradiation in a rectangular field of $10 \times 20$ $\mathrm{mm}^{2}$ for the globular Mix-Dp phantom of $20 \mathrm{~cm}$ in diameter with $4 \mathrm{MV}$ x-rays.

線量分布をFig.10に示す.90\%線量曲線は線量分布の 中心が頭頂部側に偏った流線形を示し，70\%から 10\% 線量分布曲線は楕円形状を示した。

以上，線量分布曲線形状の比較は，M-STIでは高線 量域における照射野の接合部がくびれた形状を示し た。一方，原体STIの線量分布曲線は単純な楕円の形 状を示した.

\section{2-2 線量分布曲線面積比}

MCA法の各照射法の線量分布曲線面積比の結果を Table 1に示す．高線量域の集光度の指標である90\%照 射面積 $/ 50 \%$ 照射面積比々低線量域の集光度の指標で ある50\%照射面積 $10 \%$ 照射面積比ともに，M-STIと $10 \mathrm{~mm} \phi 2$ 個の原体MCA法を比較すると優劣はほとん どなかった。しかし，それらと $10 \mathrm{~mm} \phi 3$ 個の原体MCA 法を比較すると後者は高線量域と低線量域ともに集光 度が劣っていた。

一方，歳差集光照射法の各照射法の面積比の結果を Table 2に示す．MCA法に比較し，M-STIと $10 \mathrm{~mm} \phi 2$ 個の原体STIの集光度がやや優れる結果になった。し かし，矩形の照射野ではM-STIと比較し高線量域は集 光度が劣り，低線量域は集光度が優れ，打上そ $10 \mathrm{~mm} \phi 2$ 個の原体歳差集光照射法の集光性と同等に なった. $10 \mathrm{~mm} \phi 2$ 個と $10 \mathrm{~mm} \phi 3$ 個の原体歳差集光照 射法を比較すると，高線量域掞よび低線量域ともに集 光度が劣る結果になった。

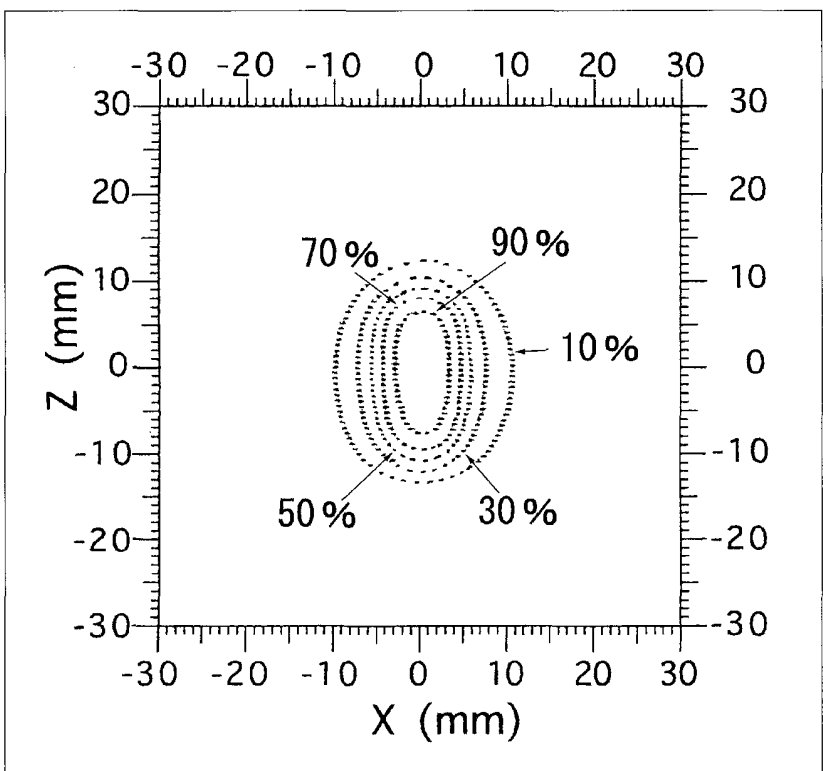

Fig. 9 Coronal isodose distribution of conformational precessional convergent irradiation matched for two fields of $10 \mathrm{~mm} \phi$ in diameter for the globular MixDp phantom of $20 \mathrm{~cm}$ in diameter with $4 \mathrm{MV}$ x-rays.

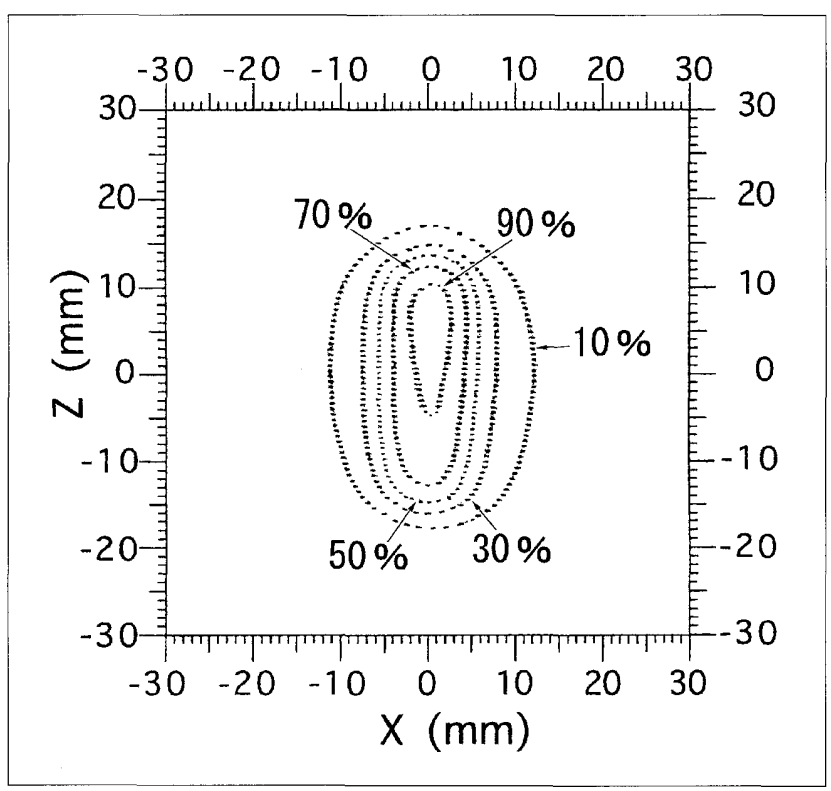

Fig. 10 Coronal isodose distribution of conformational precessional convergent irradiation matched for three fields of $10 \mathrm{~mm} \phi$ in diameter for the globular Mix-Dp phantom of $20 \mathrm{~cm}$ in diameter with 4 MV x-rays.

\section{3. 考 察}

1960年に高橋により開発された原体照射法 (conformation radiotherapy) ${ }^{26)}$ は運動照射法の一部改良型と考 えられていた29)。一方，1992年にアメリカで実用化さ れたconformal radiotherapyは標的の形状に合わせた複 雑な形をした照射野 (conformal field)による多門固定 
Table 1 Irradiated area ratios (90\% irradiated area/50\% irradiated area, and $50 \%$ irradiated area/ $10 \%$ irradiated area) of multiple noncoplanar converging arcs techniques.

The fields are multiple isocenters and conformational fields.

\begin{tabular}{|c|c|c|}
\hline $\begin{array}{l}\text { Multiple non-coplanar } \\
\text { converging arcs }\end{array}$ & $\begin{array}{c}\text { Irradiation area ratio (\%) } \\
90 \% \text { irrdiation area/ } \\
50 \% \text { irradiation area }\end{array}$ & $\begin{array}{l}\text { Irradiation area ratio (\%) } \\
50 \% \text { irrdiation area/ } \\
10 \% \text { irradiation area }\end{array}$ \\
\hline $\begin{array}{l}\text { Multiple isocenters shot } \\
10 \times 10 \mathrm{~mm}^{2} \\
+10 \times 10 \mathrm{~mm}^{2}\end{array}$ & 16.7 & 36.7 \\
\hline $\begin{array}{l}\text { Conformation field } \\
(10 \rightarrow 20) \times 10 \mathrm{~mm}^{2}\end{array}$ & 17.2 & 36.2 \\
\hline $\begin{array}{l}\text { Conformation field } \\
(10 \rightarrow 30) \times 10 \mathrm{~mm}_{2}\end{array}$ & 14.3 & 33.0 \\
\hline
\end{tabular}

Table 2 Irradiated area ratios (90\% irradiated area/50\% irradiated area and $50 \%$ irradiated area $10 \%$ irradiated area) of precessional convergent irradiation techniques.

The fields are multiple isocenters, rectangular fields, and conformational fields.

\begin{tabular}{|c|c|c|}
\hline $\begin{array}{l}\text { Precessional convergent } \\
\text { irradiation }\end{array}$ & $\begin{array}{l}\text { Irradiation area ratio (\%) } \\
90 \% \text { irrdiation area/ } \\
50 \% \text { irradiation area }\end{array}$ & $\begin{array}{l}\text { Irradiation area ratio (\%) } \\
50 \% \text { irrdiation area/ } \\
10 \% \text { irradiation area }\end{array}$ \\
\hline $\begin{array}{l}\text { Multiple isocenters shot } \\
10 \times 10 \mathrm{~mm}^{2} \\
+10 \times 10 \mathrm{~mm}^{2}\end{array}$ & 25.4 & 31.0 \\
\hline $\begin{array}{l}\text { Rectangular field } \\
10 \times 20 \mathrm{~mm}^{2}\end{array}$ & 17.2 & 36.1 \\
\hline $\begin{array}{l}\text { Conformation field } \\
\qquad(10 \rightarrow 20) \times 10 \mathrm{~mm}^{2}\end{array}$ & 27.0 & 35.4 \\
\hline $\begin{array}{l}\text { Conformation field } \\
(10 \rightarrow 30) \times 10 \mathrm{~mm}^{2}\end{array}$ & 23.0 & 28.7 \\
\hline
\end{tabular}

nar conformally SRS ${ }^{35)}$ である.こ れらの原体STIとの比較を行いたい と考えるが、その検討は次回に行 いたい.

線量分布曲線形状の比較は, MCA法および歳差集光照射法とも にM-STIでは照射野の接合部がく びれた形状を示した。一方，原体 STIは楕円形を示した。このことよ り，原体STIの線量分布曲線形状が M-STIより単純なため，標的の形 状に一致させやすいと考える。

線量分布曲線面積比による集光 度の検討では，MCA法㧈よび歳差 集光照射法ともに $10 \mathrm{~mm} \phi 2$ 個の原 体STIはM-STIとほぼ同等であっ た.

一方，歳差集光照射法における 固定矩形照射野では，M-STI と比 較すると線量分布曲線形状は楕门 形を示したが，高線量域の集光度 が低下した。

他方, MCA法と歳差集光照射法 ともに $10 \mathrm{~mm} \phi 2$ 個相当の原体STI と $10 \mathrm{~mm} \phi 3$ 個の原体STIを比較す ると, 後者は集光度が劣る結果に なった．原体STIは形状を複雑にす ると集光度が低下することを示唆 していると考える。しかし，今回 の原体STIは照射角度ごとのコリメ 一夕開度を操作したたけで，線量 配分は特に考慮していない.コリ メー夕開度と線量配分を考慮した 原体STIは，上り複雑な形状が可能 であり，集光度の低下も改善され ると考えられ，今後の課題にした い.

原体STIの向向はMCA法では体 軸から横方向にのばした方向，歳 差集光照射法では体軸力向にのば

照射を，能率良く実施するために開発されたものであ る29). 両者は日本におろいて共に原体照射法と呼ばれてい る29). われわれが検討した原体STIは高橋の発想に基づ いた照射法であり，塩田らの多門歳差集光照射法19), 中川らの歳差集光原体照射34)も同じ原理である.

一方，後者の原理に基ついた原体STIはVivianらが アイソ・センタ上にて最小 $3 \mathrm{~mm}$ 幅のマイクロ・マル チリーフ・コリメー夕を使用した固定多門non-copla-
した方向で，あえて違う方向にて検討を行った：その 理由はそれぞれの線量分布が良好な結果を得た得意な 方向で比較を行ったためである。しかし，欠点を明ら かにするためにも標的の形状への適性を調べるため， いろいろな方向，さらに複雑な標的の形状にて検討す る必要がある。さらに, 今回の研究では線量分布曲線 照射面積を測定し，高線量域と低線量域の集光度を求 めた。理想的には照射容積を求めるべきであるが，線 
量分布曲線形状が複雑な形状を示しフィルム法では照 射容積を求めるのが困難であったため，面積計を用い 等線量曲線の面積を求めた。しかし，dose-volume histogram解析 $(\mathrm{DVH})^{36)}$ を用いれば照射容積の比較が より正確に行えると考える。これらの検討は次の機会 に行いたい.

\section{4. 結 語}

1) 原体STIの線量分布曲線はM-STIに比較し，単純な 楕円の形状を示した.

2) 原体STIは線量分布曲線が単純な形状であるため, 標的の形状に一致させやすい。

3 ) 単純な原体STIの集光度はM-STIとほほ同等であっ た。
4）原体STには形状を複雑にすると集光度が低下した.

\section{謝 辞}

稿を終えるにあたり，ご教示をいただきました藤田 保健衛生大学医学部放射線医学教室古賀佑彦教授に深 謝いたします。また，本研究にご協力いただきました 藤田保健衛生大学衛生学部㧍よび藤田保健衛生大学病 院放射線部の各位，資料を快くご提供いたたききした エレク夕株式会社, 千代田テクノル株式会社, 東洋メ ディック株式会社の関係各位にこの場を借りて深く御 礼申し上げます。

この論文の要旨は平成 7 年度 $(1995) \mathrm{X}$ 線発見100周 年記念全国放射線技師総合学術大会にて発表した.

\section{参考文献}

1) Leksell L: The stereotactic method and radiosurgery of the brain. Acta Chir Scand, 102, 316-319,(1951).

2) Leksell L: Cerebral radiosurgery. Acta Chir Scand, 134, 585$595,(1968)$

3) Steiner L, Leksell L, Greitz T, et al.: Stereotaxic radiosurgery for cerebral arteriovenous malformations. Acta Chir Scand, 138, 459-464, (1972).

4) Steiner L, Leksell L, Forster DM, et al.: Stereotaxic radiosurgery in intra-cranial arteriovenous malformations. Acta Neurochir Suppl, 21, 195-209, (1974).

5) Backlund EO: Stereotactic Radiosurgery in Intracranial Tumors and Vascular Malformations. pp.17-34, Springer-Verlag, Stockholm, (1982).

6) Kjellberg RN, Hanamura T, Davis KJ, et al.: Bragg-peak proton-beam therapy for arteriovenous malformations of the brain. N Engl J Med, 309, 269-274, (1983).

7) Fabrikant JI, Lyman JT, and Hosobuchi Y: Stereotaxic heavyion Bragg peak radiosurgery for intracranial vascular disorders: Method for treatment of deep arteriovenous malformations. Br J Radio, 57, 479-490,(1984).

8) Dunbar SF, Tarbell NJ, Kooy HM, et al.: Stereotactic radiotherapy for pediatric and adult brain tumors; Preliminary report. Int J Radiat Oncol Biol Phys, 30, 531-539, (1994).

9）鈴木恵士郎，白土博樹：ライナックによるラジオサージエ リ-. INNERVISION 10(5), 42-45, (1995).

10) Hartmann GH, Schlegel W, Sturm V, et al.: Cerebral radiation surgery using moving field irradiation at a linear accelerator facility. Int J Radiat Oncol Biol Phys, 11 (6), 1185 $1192,(1985)$

11) Betti OO and Derechinsky VE: Hyper-selective encephalic irradiation with linear accelerator. Acta Neurochir, SuppI, 33, 385 390, (1984).

12) Colombo F, Benedetti A, Pozza F, et al.: External stereotactic irradiation by linear accelerator. Neurosurgery, 16, 154 $160,(1985)$.

13）宮原拫士，古賀健治，西川 清，他：CT guided stereotactic cerebral irradiation by linear accelerator一照射手技と線量 分布一。日医放会誌，46(8)，1063-1065,(1986).

14）安野泰史，古賀佑彦，鈴木昇一，他：Convergent radiotherapy by liniac X-ray. 放治システム研 (suppl 2)，122124, (1985).

15) Anno H, Koga S, Takeuchi A, et al.: A technique of precessional convergent radiotherapy with linear accelerator. Radiology, (suppl 157), 311,(1985).

16)鈴木昇一，立木秀一，沢田武司：放射線治療における照射 法の研究一歳差集光照射法. 日放技会誌，35(2)，146172, (1988).

17) 安野泰史, 古賀佑彦，竹内 昭：4MVX線による歳差集光 照射法の研究. 日本医放会誌，48(5)，608-614,(1988).

18) 寺尾栄夫, 西川秀人, 大石仁志, 他：新しい原理, 装置に よるlinear acceleratorを用いたradiosurgery一その原理・装 置と臨床経験. 脳外，20，583-592，（1992）。

19)塩田 晃，福井利治，田原和彦，他：多門歳差集光照射法 の検討. 日放技学誌，52(9)，1158，(1996).

20) Podgorsak EB, Olivier A, Pla M, et al.: Dynamic stereotactic radiosurgery. Int J Radiat Oncol Biol Phys, 14, 115-126, (1988).

21）堀川よしみ, 石垣武男, 佐久間貞行：ヘルメット式固定具 を用いたライナックによるステレオタキシック照射の試 み. 日本医放会誌，51(9)，1053-1058，(1991)

22) 烱 昌幸, 泉隆, 城戸五郎, 他：リニアックによる Stereotactic Radiosurgeryの検討. 日放技学誌，48(5)，770773, (1992).

23）中川恵一, 青木幸昌, 佐々木康人, 他：ガンマナイフ治療 の現状と展望. INNERVISION，10(5)，34-40，(1995).

24) 田中清明：XKnife ${ }^{R}$ システムによる定位放射線治療. INNERVISION, 12(10)，15-20，(1997).

25) Nedzi LA, Kooy H, Alexander III E, et al.: Variables associated with the development of complications from radiosurgery of intracranial tumors. Int J Radiat Oncol Biol Phys, 21 (3), 591-599, (1991).

26) 高橋信次：Co-60廻転照射に於ける新しい工夫. 臨床放射 
線，5，653-658，(1960).

27) 植田俊男：原体照射法の技術と応用. 日放技学誌, 32 (9), 217-248, (1976).

28) 森田皓三：原体照射法 (conformal RT) とその発展. 癌の臨 床，40，33-46，(1994).

29）森田皓三：原体照射法．INNERVISION，12(10)，39-42, (1997).

30) 藪谷俊峰，鈴木昇一，澤田武司：Radiosurgeryの基礎的検 討 (原体歳差集光照射法の可能性について). 日放技会誌, 42(9)，1441，(1995).

31 ) 藪谷俊峰, 井田義宏, 澤田武司: 水等価ファントムの比較 検討. 日放技学誌，54(6)，747-753，(1998).

32) 平林久枝：放射線治療領域におけるフィルム線量測定法の
有効利用と問題点. 日放技学誌，51(1)，48-61，(1995).

33) 後藤紳一：写真フィルムによるナロー・ビームの線量評 価. 放医物理, 17(1)，9-14，(1997).

34）中川恵一, 青木幸昌, 㖟藤正治, 他：Cアームライナック と歳差集光原体照射. INNERVISION，14(10)，96-99 (1999).

35) Cosgrove VP, Jahn U, Pfaender M, et al.: Commissioning of a micro multi-leaf collimator and planning system for stereotactic radiosurgery. Radiotherapy and Oncology, 50, 325336, (1999).

36) Drezymala RE, Mohan R, Brewster L, et al.: Dose-volume histograms. Int J Radiat Oncol Biol Phys, 21, 71-78, (1991).

Fig. 1 multiple non-coplanar converging arcs法はファントム中心に，軸位断面より正中面に向け $15^{\circ} ， 45^{\circ}, 75^{\circ}$ の左右対称にarc数 6 , arc角度 $110^{\circ}$ にて照射した。（a) は冠状断面，(b) は矢状断面に扮ける照射角度を示す。

Fig. 2 歳差集光照射法は $8^{\circ}$ 刻みの 11 門にて照射した.

Fig. 3 原体定位的放射線照射の照射角度 $\theta$ ごとのコリメータ開度L(アイソセンター上での一辺の長さで表す)を $10 \mathrm{~mm} \phi$ 照射野 2 個のmultiple isocentersに相当するモデルにてコリメータ開度Lの計算過程を示す.

Fig. 4 multiple non-coplanar converging arcs法10mm $\phi 2$ 個でのmultiple isocentersの線量分布を示す. 直径20cmのMix-Dpファン トムを使用し，測定方向は冠状断面，4MV X線を使用した。

Fig. $510 \mathrm{~mm} \phi 2$ 個に相当する原体定位的multiple non-coplanar converging arcs照射法の線量分布を示す. 直径 $20 \mathrm{~cm} の \mathrm{Mix}-\mathrm{Dp}$ フ アントムを使用し，测定方向は冠状断面，4MV X線を使用した。

Fig. $610 \mathrm{~mm} \phi 3$ 個に相当する原体定位的multiple non-coplanar converging arcs照射法の線量分布を示す. 直径 $20 \mathrm{~cm}$ のix-Dpつ アントムを使用し，測定方向は冠状断面，4MV X線を使用した.

Fig. 7 歳差集光照射法 $10 \mathrm{~mm} \phi 2$ 個でのmultiple isocentersの線量分布を示す．直径 $20 \mathrm{~cm}$ のix-Dpファントムを使用し，測定方向 は冠状断面，4MV X線を使用した。

Fig. $810 \mathrm{~mm} \phi 2$ 個に相当する矩形照射野での歳差集光照射法の線量分布を示す。直径 $20 \mathrm{~cm} の \mathrm{Mix}-\mathrm{Dp}$ ファントムを使用し，測定 方向は冠状断面，4MV X線を使用した。

Fig. $910 \mathrm{~mm} \phi 2$ 個に相当する原体定位的歳差集光照射法の線量分布を示す．直径 $20 \mathrm{~cm}$ のix-Dpファントムを使用し，測定方向 は冠状断面, 4MV X線を使用した。

Fig. $1010 \mathrm{~mm} \phi 3$ 個に相当する原体定位的歳差集光照射法の線量分布を示す．直径 $20 \mathrm{~cm} の \mathrm{Mix}-\mathrm{Dp}$ ファントムを使用し，測定方向 は冠状断面，4MV X線を使用した。

Table 1 multiple non-coplanar converging arcs法に扔ける照射面積比の測定結果.

Table 2 歳差集光照射法に㧈ける照射面積比の測定結果. 